\title{
EEA Immigration Symposium Introduction
}

\author{
Andrew J. Padovani ${ }^{1}$. Cynthia Bansak ${ }^{2}$
}

Published online: 12 December 2019

(C) EEA 2019

In this issue, we include seven papers related to current issues in immigration policy as a Special Issue on Immigration. Most papers in this volume highlight the variety of ways in which government policy affects the assimilation process for immigrants in the USA; this is a topic that is mostly ignored in the current immigration debate (Felter and Renwick 2019) but is no less important. Aptekar (2015) notes that immigrants describe assimilation as the final step in the process of building a life in their new country - getting an education, finding a job, raising a family, buying a house, and becoming active in the community. While the debate continues over how to reform immigration policy, the papers in this issue show policymakers should not lose sight of the challenges immigrants face building their new American identity and supporting those they left behind. Brief summaries of the papers are provided below.

Wang and Lofstrom explore an unexpected effect of tightening immigration policies in the USA resulting from the terrorist attacks on September 11, 2001 (9/11): changes in immigrant self-employment. After 9/11, state and local governments stepped up enforcement of immigration policies, with the primary target being undocumented Mexican immigrants in the workplace. The existing literature focusing on wages and employment finds that increased enforcement negatively affected the labor market outcomes of undocumented Mexican immigrants. As a result, undocumented Mexican immigrants are turning to self-employment (Wang 2019) instead of participating in the traditional labor market. Wang and Lofstrom hypothesize that Mexican immigrants are turning to self-employment out of necessity, rather than because of new opportunities for self-employment. Using the $9 / 11$ terrorist attacks as an exogenous, unexpected shock to enforcement of immigration policies, they separately identify the effect on opportunity and necessity self-employment. The authors find that self-employment increased among Mexican immigrants

Cynthia Bansak

cbansak@stlawu.edu

Andrew J. Padovani

ajpadovani@ucdavis.edu

1 University of California, Davis, Davis, USA

2 St. Lawrence University, Canton, USA 
compared to low-education whites, with necessary self-employment increasing most. This result is consistent with their hypothesis that self-employment increased out of necessity rather than opportunity.

Dziadula examines a different side of assimilation using new American Community Survey (ACS) questions to better understand how a spouse's citizenship status affects the probability of an immigrant becoming a US citizen. The existing literature shows immigrants who marry US-born citizens are more likely to naturalize (Chiswick and Miller 2005) but have been unable to identify the citizenship status of foreign-born spouses at the time of their marriage. After 2008, the ACS began asking for both the year of most recent marriage and the year of naturalization, allowing the researcher to determine the citizenship status of both spouses at the time of the survey and at the time of their most recent marriage. Dziadula expected foreignborn people who married naturalized foreign-born spouses to themselves be more likely to become citizens. To estimate the probability of naturalization for those persons marrying foreign-born citizens, Dziadula utilizes the Cox proportional hazards model. The author confirms results from previous research that having a citizen spouse increases the probability of naturalization, and additionally finds support for the hypothesis that this extends to having a foreign-born, naturalized spouse. Indeed, Dziadula estimates the probability of gaining citizenship is greater for foreign-born persons who marry naturalized foreign-born than those who marry US-born citizens. The intuition for this result is straightforward: Citizenship grants many benefits to those immigrants who pursue it, and immigrants do naturalize once they are eligible (Dziadula 2018).

In a paper by Mundra, the author examines how immigrant and minority people fared in the housing boom and subsequent bust of the 2000s. The US government has implemented several initiatives promoting first-time homeownership during the past few decades, including Frannie Mae and Freddie Mac targeting low-income homebuyers with subprime mortgages in the 1990s and early 2000s (Frame and White 2005). Mundra uses data from the 2009 American Housing Survey (AHS) to determine how subprime lending improved the gap in the rate of homeownership among immigrants and minorities compared to natives and whites and to understand how the subsequent housing bust of 2007 and 2008 affected the rate of exit from homeownership among immigrants and minorities who obtained mortgages during the peak of subprime lending compared to natives and whites. The author finds the rate of homeownership among immigrants and minorities did not improve during the housing boom compared to natives and whites. Additionally, the hazard ratio for exit from homeownership was highest among minorities and non-citizen immigrants, particularly for mortgages originating between 2004 and 2006, the peak period of subprime lending. In sum, those groups with the lowest levels of education and income-black and immigrant households-benefitted the least subprime lending and had the highest probability of exiting homeownership during the Great Recession.

In Liu and Song, the authors compare two methods to identify likely undocumented individuals in survey data. The authors find that their proposed residual method is preferred for matching a number of official statistics. Both methods produce similar policy conclusions although with effect sizes in different magnitudes. 
In Chi and Coon et al., the authors look at the visa process for oversubscribed countries. In particular, the authors focus on China, India, Mexico, and the Philippines compared to the rest of the world to look for differences in earnings between naturalized and non-naturalized immigrants. The research question asks whether the naturalization premium varies between immigrants from oversubscribed countries compared to immigrants from other countries. Results are mixed: Premiums are larger than average for Chinese, Mexican, and Filipino immigrants, but smaller than average for Indian immigrants. These premiums from naturalization more than offset country-of-origin wage penalties for Chinese immigrants, but only partially offset the penalty for Mexican and Filipino immigrants. Interestingly, the authors find no evidence of a naturalization premium for immigrants from the rest of the world.

In Carstensen et al., the authors examine second-generation immigrants' entry to higher education. Specifically, using a survey of first-semester college students in the European Higher Education Area-an area incorporating 48 member statesthey test whether there are differences in institutional choices between native and second-generation immigrant students. The focus is on not only the schools selected but the employment opportunities embedded in the curriculum and the opportunities available afterward. The paper combines a theoretical choice model with an empirical analysis. The theoretical model incorporates several strands of educational investment theory such as a human capital model with selection, segmented markets, discrimination, and the ability to overinvest. It also allows for the very recent ethnic spillover effects included in Borjas et al. (2019). The empirical work focuses on business and economics majors, and the results provide new insights into individual and immigrant-specific preferences for certain professional profiles and university types. Findings suggest that second-generation migrants differ in terms of their college choice and jobs after college. Within this heterogeneity, they find that those with stronger language skills in their host country are more likely to focus on university studies with an employment focus.

In the last paper, Simpson and Sparber examine the determinants of remittances from the USA using the Current Population Survey (CPS) data for the first time; in particular, they assess the role of push, pull, and distance factors in money transfers abroad. They find an elasticity of remittances with respect to earnings ranging between 0.2 and 0.3 with a greater responsiveness for households with a greater share of women. Remittances are also driven by push and pull factors such as education, family structure, GDP in the origin country, and the distance between countries. These results can help inform policymakers who aim to facilitate the transmission of financial flows between countries and understand the key determinants of these flows.

\section{References}

Aptekar, S. 2015. The Road to Citizenship: What Naturalization Means for Immigrants and the United States. New Brunswick: Rutgers University Press. 
Borjas, George J., Barry R. Chiswick, and Benjamin Elsner. 2019. Foundations of Migration Economics, IZA Prize in Labor Economics. Oxford: Oxford University Press.

Chiswick, Barry R., and Paul W. Miller. 2005. Linguistic Distance: A Quantitative Measure of the Distance Between English and Other Languages. Journal of Multilingual and Multicultural Development 26(August): 1-11.

Dziadula, Eva. 2018. Timing of Naturalization Among US Immigrants. Journal of International Migration and Integration 19(3): 791-811.

Felter, Claire and Danielle Renwick. 2019. "The U.S. Immigration Debate” Renewing America: Backgrounder. New York: Council on Foreign Relations.

Frame, W., and L.J. White. 2005. Fussing and Fuming Over Fannie and Freddie: How Much Smoke, How Much Fire? Journal of Economic Perspectives 19(2): 159-184.

Wang, Chunbei. 2019. Tightened Immigration Policies and the Self-Employment Dynamics of Mexican Immigrants. Journal of Policy Analysis and Management 38: 944-977.

Publisher's Note Springer Nature remains neutral with regard to jurisdictional claims in published maps and institutional affiliations. 